\title{
OBYEKTIVASI SIKAP TOLERANSI ANAK DALAM PENDIDIKAN ISLAM MULTIKULTURAL KELUARGA MULTI AGAMA
}

\author{
Oleh: Nasruddin \\ Dosen UIN Sunan Ampel Surabaya
}

Email : Nasruddin@uinsby.ac.id

\begin{abstract}
Abstrak
Setelah orang tua dalam keluarga multi agama di masyarakat Balun melakukan penyesuaian diri terhadap realitas sosial sebelumnya, dan ketika realitas sosial yang baru terbentuk, mereka mau tidak mau harus terlibat di dalamnnya meskipun realitas baru ini sendiri mengalami 'tarik ulur' atau negosiasi di antara individu-individu yang ada di masyarakat Balun, termasuk orang tua dalam keluarga multi agama sebelum realitas baru tersebut terlembagakan atau terinstitusionalisasikan baik di dalam pikiran, tindakan, perilaku atau lainnya. Dengan kata lain, realitas sosial baru yang berbentuk beragam sikap toleransi yang ditampilkan oleh anak keluarga multi agama dalam kehidupan ini lambat laun menjadi bagian hidup yang tak terpisahkan dari kehidupan keseharian mereka.
\end{abstract}

Kata kunci: institusionalisasi, anak, realitas sosial, keluarga

\section{Abstract}

After parents in a multi-religious family in the Balun community adjust themselves to previous social realities, and when new social realities are formed, they inevitably have to be involved in them even though this new reality itself experiences 'tug-of-war' or negotiations between individuals individuals in the Balun community, including parents in multi-religious families before the new reality is institutionalized or institutionalized both in thought, action, behavior or otherwise. In other words, the new social reality in the form of a variety of tolerance attitudes which are displayed by the children of multi-religious families in this life gradually becomes an inseparable part of their daily lives.

Keywords: institutionalization, children, social reality, family

\section{PENDAHULUAN}

Dalam konteks relasi antar agama, tidak ada desa yang paling terkenal di wilayah kabupaten Lamongan, kecuali desa Balun. Desa ini tidak hanya dihuni oleh umat Islam saja, melainkan juga oleh umat-umat agama lain seperti Kristen dan Hindu. Keberadaan agama Kristen dan Hindu tidak hanya diakui oleh pemerintahan desa Balun, tetapi juga diayomi keberadaan 
mereka. Bahkan, setiap aktivitas keagamaan kedua agama ini (Kristen dan Hindu) juga dilindungi. Pengakuan, pengayoman dan perlindungan oleh pemerintahan desa Balun terhadap agama-agama yang ada ini menjadikan desa Balun terasa sangat istimewa dan langka jika dibandingkan dengan desa-desa yang ada di wilayah Lamongan lainnya. Sehingga, tidak mengherankan jika desa Balun dikenal sebagai "desa Pancasila."

Keterkenalan desa Balun sebagai desa Pancasila ternyata tidak hanya pada level kabupaten, propinsi, maupun nasional saja, melainkan sudah merambah dunia internasional. Hal ini dibuktikan dengan adanya kunjungan warga negara Malaysia, ${ }^{1}$ Belgia dan Korea. ${ }^{2}$ Mereka datang ke Balun untuk membuktikan dan ingin menyaksikan langsung tentang kehidupan keberagamaan yang damai dan keharmonisan antar umat beragama dalam interaksi sosial. Pembuktikan dan penyaksia warga negara asing ini terhadap kehidapan yang harmoni dan toleran di antara umat beragama di Balun ini menegaskan bahwa sebutan Balun sebagai desa Pancasila bukanlah sekedar klaim, melainkan sesuai dengan fakta dan kenyataan yang ada.

Umat beragama di Balun berusaha untuk saling bertoleansi. Sikap toleran antar umat ini misalnya ditunjukkan umat Islam hanya menggunakan loud speaker dalam masjid ketika mereka sedang melakukan dzikir setelah sholat maghrib berjamaah, karena pada saat yang bersamaan umat Hindu juga sedang melaksanakan puja bakti. ${ }^{3}$ Sikap toleransi ini didasarkan pada kesadaran akan pentingnya sikap saling mengerti dan memahami, menjaga kedamaian, kerukunan dan keharmonisan social yang sudah teripta dan terjaga selama ini.

Bapak AW, tokoh agama Hindu desa Balun, menuturkan bahwa ia sangat bisa memahami penggunaan loud speaker menara masjid, karena umat Islam merupakan umat yang paling banyak pemeluknya di desa Balun, dan sebagian besar mereka juga tidak hidup di sekitar atau dekat dengan masjid (tinggal di pinggir desa Balun), sehingga penggunaan penggunaan loud speaker menara masjid merupakan suatu hal yang bisa dimaklumi. ${ }^{4}$

Sikap toleransi umat Islam di Balun juga diakui oleh tokoh agama Kristen, Pendeta Sut, yang menyatakan bahwa umat Islam tidak membunyikan loud speaker menara masjid ketika mereka menyaksikan umat Kristen di gereja sedang melakukan kebaktian atau misa. ${ }^{5}$ Sikap ini tentu menegaskan sebuah bentuk kesadaran keagamaan dan toleransi antar

\footnotetext{
${ }^{1}$ Wawacara mantan dengan Kaur Kesra, R, dan anggota Bappeda Lamongan, M, 11 November 2016).'

${ }^{2}$ Peristiwa terjadi pada bulan November 2016.

${ }^{3}$ Wawancara dengan Sam, 4 November 2016.

${ }^{4}$ Wawancara dengan Pak AW (tokoh Hindu), Jum'at, 9 Desember 2016.

${ }^{5}$ Wawancara dengan Pendeta Sut di rumahnya, tanggal 3 Desember 2016.
} 
umat beragama, khusunya umat Islam dalam rangka menjaga keharmonisan, kedamaian, kerukunan dan kenyamanan hidup bersama.

Lembaga pendidikan formal seperti TK Pembangunan, TKM Jamhar, SDN I Balun, SDN II Balun, SDN III Balun dan MI Tarbiyatus Sibyan memberikan kontribusi bagi justifikasi atau pembenaran serta pemeliharaan sikap toleransi yang sudah dimiliki diri anak didik mereka. Lembaga pendidikan non formal seperti pondok pesantren (ponpes), les atau kursusan juga memberikan sumbangsih nyata bagi pemeliharaan dan pengembangan sikap toleransi anak. Ponpes yang ada di Balun tidak mengajarkan nilai-nilai kekerasan, kekakuan, dan keekslusifan, melainkan menebarkan dan melestarikan nilai-nilai Islam yang ramah, moderat, toleran, seimbang dengan berbasiskan pada ciri ke-Indonesia-an. Lembaga pendidikan informal (baca: keluarga) memainkan peranan yang sangat penting dan signifikan dalam melahirkan sikap toleransi anak karena anakanak sebelum belajar di sekolah atau masyarakat, mereka terlebih dahulu mempelajari sesuatu dalam keluarga mereka.

Keluarga di desa Balun memegang peran yang sangat signifikan dan menentukan dalam pengkonstruksian sikap toleransi anak, karena waktu anak bersama keluarga di ruma jauh lebih banyak dibandingkan dengan para guru di sekolah maupun di ponpes. Anak-anak di sekolah hanya menghabiskan waktu antara 2,5 sampai 8 jam sehari, selebihnya mereka menghabiskan waktu bersama keluarga di rumah. Dengan kata lain, anakanak bisa menghabiskan waktu 16 jam bersama keluarga mereka di rumah, sehingga, keluarga memiliki kesempatan yang luas dan leluasa dalam membentuk dan mengkonstruksi sikap toleransi anak.

Dalam mengkonstruksi sikap toleransi anak, orang tua di Balun tidak hanya mengajak anak-anak menghadiri acara-acara selamatan, kenduri dan sejenisnya, melainkan juga membiarkan mereka belajar dan bermain bersama di dalam atau di luar rumah.

Dengan kata lain, pendidikan dalam keluarga multi agama tersebut memegang peranan yang sangat penting dan siginifikan sekali dalam mengobyektivasi sikap toleransi pada diri anak di Balun, sehingga, kajian yang mengstudi tentang obyektivasi sikap toleransi anak di "desa Pancasila" Balun Turi Lamongan ini tidak hanya menjadi sangat menarik, tetapi sudah sangat penting untuk dilakukan sebagai model dalam pengkonstruksian sikap toleransi di daerah atau wilayah lain.

Dengan merujuk kepada konteks di atas, fokus utama kajian ini adalah Bagaimana keluarga multi agama mengobyektivasi sikap toleransi anak di "desa Pancasila" Balun Turi Lamongan? 


\section{METODE}

Metode yang dipakai dalam penelitian ini adalah metode kualitatif, ${ }^{6}$ karena (i) mempertanyakan 'apa dan bagaimana. ${ }^{7}$ Sementara itu, paradigma yang dipakai dalam penelitian ini adalah paradigma post-positivistik ${ }^{8}$ dengan jenis fenomenologi,${ }^{9}$ karena peneliti ingin mencari atau menemukan makna di balik realitas sosial atau fakta yang ada ${ }^{10}$ di desa Balun, dan bagaimana subyek penelitian (keluarga multi agama) mengalami realitas sosial atau fakta tersebut. Jenis fenomenologis yang dipakai adalah transcendental empiris, karena, peneliti menafsirkan dan menyimpulkan

${ }^{6}$ Alison Mackey. Second Language Research: Methodology and Design. (New Jersey: Lawrence Erlbaum Associates, Inc. 2005), 162-7, lihat juga Sharlene Nagy and Hesse-Biber. Mixed Methods Research: Merging Theory with Practice. (New York: The Guilford Press, 2010), 67-72; Imron Arifin. Penelitian Kualitatif dalam Ilmu-ilmu Sosial dan Keagamaan. (Malang: Kalimasahada Press, 1994), 10-12, 16-21; Mudrajat Kuncoro. Metode Riset. (Jakarta: Erlangga. 2003), 2-3; Robert Bogdan \& Steven J. Taylor. Dasardasar Penelitian Kualitatif. Terj. A. Khozin Afandi. (Surabaya: Usaha Nasional, 1975), 2630, 36-37; Bruce L Berg. Qualitative Research Methods for the Social Science. (USA: Allyn dan Bacon, 1989), 1-7; Thomas R. Lindlof. Qualitative Communication Research Methods. (USA: SAGE Publications, Inc. 1995), 18-22, 56-58; David Silvermen. Interpreting Qualitative Data: Methods for Analyzing Talk, Text, and Interaction. Great Britain: the Crowell Press, ltd, 20-29.

${ }^{7}$ Thomas R. Lindlof. Qualitative Communication Research Methods. (USA: SAGE Publications, Inc. 1995), 69-80, 82, 88, 90 dan 94; Mudrajat Kuncoro. Metode Riset. (Jakarta: Erlangga. 2003), 23-26, 33-35; Bruce L Berg. Qualitative Research Methods for the Social Science. (USA: Allyn dan Bacon, 1989), 2-8; Matthew MiELs B \& A. Michael Huberman. Analisis Data Kualitatif. Terj. Tjejep Rohendi. (Jakarta: UI, tt), 38-45; Donald Ary et.all. Introduction to Research in Education. USA: Holt Rinehart and Winston, tt, 4155; James Dean Brown. Understanding Research in Second Language ELarning. NY: (Cambridge Univ. Press, tt), 211-220.

${ }^{8}$ Jan Jocker dan Bartjan Pennink. The Essence of Research Methodology: A Concise Guide for Master and PhD Students in Management Science. (Berlin: Springer, 2010), 80-81.

${ }^{9}$ Untuk memahami ELbih jelas dan detail tentang fenomenologi, lihat Imron Arifin. Op.Cit, 45-62; Mudrajat Kuncoro. Op.Cit, 23-26, 8-9; Bruce L Berg. Op.Cit. 51-78; Donald Ary et.all. Op.Cit. hal, 295-324; Robert Bogdan \& S Knopp BikELn. Op.Cit. hal, 37-47, 254-294; James Spreadly. Participant Observation. (USA: Holt Rinehart and Winston, 1980), hal,175-179. Imron Arifin. Op.Cit,45-56 (Orientasi Teoritik Pendekatan dan Metode); Robert Bogdan \& Steven J. Taylor. Dasar-dasar Penelitian Kualitatif. Terj. A. Khozin Afandi. (Surabaya: Usaha Nasional, 1975), 44-50; Bruce L Berg. Qualitative Research Methods for the Social Science. (USA: Allyn dan Bacon, 1989), hal, 6-7; Thomas R. Lindlof. Qualitative Communication Research Methods. (USA: SAGE Publications, Inc. 1995), 27-33, 40-44, 46-48, 94; David Silvermen. Interpreting Qualitative Data: Methods for Analyzing Talk, Text, and Interaction. (Great Britain: the Crowell Press, ltd, 1995), 8 19.

${ }^{10}$ John W. Creswell. Penelitian Kualitatif \& Desain Riset. (Yogyakarta: Pustaka Pelajar, 2014), 105-281. 
fenomena atau realitas di Balun dengan menyandarkan pada tafsiran subyek penelitian. ${ }^{11}$

Lokasi penelitian ini adalah desa 'Pancasila' Balun Turi Lamongan. Desa ini dijadikan lokasi penelitian karena (i) memiliki keunikan dan kekhasan tersendiri dibandingkan dengan desa-desa lain yang ada di wilayah kabupaten Lamongan, yakni desa ini memiliki tiga agama resmi (Islam, Kristen dan Hindu), (ii) rumah ibadah ketiga agama ini berdiri saling bersebelahan dan berhadapan, dan mensimbolkan kerharmonisan dan kerukunan, dan (iii) umat ketiga agama ini tidak pernah terlibat konflik, sebaliknya mereka hidup dengan rukun, harmoni dan saling bertoleransi.

Instrumen penelitian adalah peneliti sendiri, karena peneliti bisa (1) bereaksi terhadap segala stimulus dari lokasi penelitian yang harus diperkirakan memiliki makna atau tidak bagi penelitian; (2) berinteraksi dengan situasi dan keadaan yang senantiasa berubah pada lokasi penelitian; (3) menyesuaikan diri dengan segala keadaan yang ada pada lokasi penelitian dan mampu mengumpulkan beragam data sekaligus; (4) menangkap situasi yang ada dan terjadi di lokasi penelitian secara keseluruhan; (5) memahami dan meyelami interaksi yang terjadi antar manusia pada lokasi penelitian; (6) segera menganalisis data yang diperoELh dari lokasi penelitian; dan (7) mengambil kesimpulan berdasarkan data yang diperoleh di lokasi penelitian dengan segera. ${ }^{12}$

Sumber data dalam penelitian ini berupa (i) sumber data primer, (ii) sumber data sekunder, dan (iii) sumber data pelengkap. Sumber data primer penelitian ini adalah orang tua dan anggota keluarga multi agama. Sumber data sekunder dalam penelitian ini adalah anggota keluarga multi agama yang beragama non Islam. Sedangkan, sumber data pelengkap dalam penelitian ini adalah masyarakat Balun dan dokumen-dokumen tentang pembentukan sikap toleransi terhadap anak pada masyarakat Balun, terutama pada keluarga multi agama.

Data dalam penelitian ini dibedakan menjadi dua, yaitu: (1) data emik, dan (2) data etik. Data emik dalam penelitian ini adalah informasi, keterangan, respon, pemikiran, perbuatan atau tingkah laku, dan lain sebagainya yang berasal dari sumber data harus memiliki hubungan dengan fokus penelitian, yaitu obyektivasi sikap toleransi pada anak oleh orang atau anggota keluarga multi agama. Sedangkan, data etik dalam penelitian ini adalah data tafsiran atau interpretasi peneliti terhadap konstruksi sikap toleransi pada anak yang dilakukan oleh orang tua atau anggota keluarga multi agama.

${ }^{11}$ Ibid. 110.

${ }^{12}$ M. Djunaidi Ghony dan Fauzan Almanshur. Op.Cit, 96-97. 
Teknik pengumpulan data dalam penelitian meliputi: observasi partisipatif, wawancara mendalam, dan studi dokumentasi secara menyeluruh. ${ }^{13}$ Teknik observasi partisipatif dipakai, karena peneliti bisa memperhatikan (a) ruang atau tempat, (b) pelaku, (c) kegiatan, (d) media, sarana atau alat, (e) waktu, (f) peristiwa, (g) tujuan, dan (h) perasaan. ${ }^{14}$ Peneliti menggunakan wawancara mendalam, karena peneliti berusaha menggali data tidak saja apa yang diketahui dan dialami subyek penelitian (baca: informan), tetapi apa yang tersembunyi jauh di balik aktivitas yang dilakukan oleh subyek penelitian itu sendiri, termasuk pengobyektivasian sikap toleransi anak. Dalam teknik ini, peneliti juga bisa mempertanyakan hal-hal yang bersifat lintas waktu, baik masa dulu, masa kini dan masa yang akan datang. ${ }^{15}$ Teknik studi dokumentasi dipakai, karena peneliti ingin mengumpulkan data berupa peninggalan tertulis, seperti arsip-arsip, file-file resmi yang berisi atas beragam peristiwa, kejadian, fenomena dan lain sebagainya yang terkait dengan masalah atau fokus penelitian. ${ }^{16}$

Untuk menguji keabsahan data penelitian, peneliti menggunakan uji kredibilitas data (validitas internal) ${ }^{17}$ karena uji keabsahan data ini dianggap lebih pas dan cocok dalam konteks penelitian kualitatif dan dibenarkan secara akademik melalui 7 teknik, yaitu: perpanjangan pengamatan, peningkatan ketekunan, tringulasi, ${ }^{18}$ focused group discussion (FGD), member check, ${ }^{19}$ analisis kasus negatif ${ }^{20}$ dan penggunaan referensial. ${ }^{21}$

${ }^{13}$ Yogesh Kumar Singh. Fundamental of Research Methodology and Statistic. (Delhi: New Age International, 2006), 212-222, lihat juga Geoffrey Marczyk, David DeMatteo, and David Festinger. Essentials of Behavioral Science Series. (New Jersey: John WiELy \& Sons, Inc, 2005), 95-123, Cavallo, Roger E. The RoEL of Systems Methodology in Social Sciences Research. (Boston: Martinus Nijhoff Publishing, 1979), 139-143, Alison Mackey,. Second Language Research: Methodology and Design. (New Jersey: Lawrence Erlbaum Associates, Inc. 2005), 173-8; Imron Arifin. Op.Cit., 45-56; Robert Bogdan \& Steven J. Taylor. Op.Cit, 31-33, 59-77, 81-125, 157-190; Bruce L Berg. Op.Cit, 13-22, 26-40, 4-5; Thomas R. Lindlof. Op.Cit., 124-130, 132, 135-139, 153-160, 163-194, Matthew MiELs B \& A. Michael Huberman. Analisis Data Kualitatif. Terj. Tjejep Rohendi. (Jakarta: UI, tt), 58-72; Donald Ary et.all. Op.Cit, 129-136, 173-194.

${ }^{14}$ Parsudi Suparlan. Metode Penelitian Kualitatif. Jakarta: Program Kajian Wilayah Amerika UI, 1994, 66-67. Lihat juga, M. Djunaidi Ghony dan Fauzan Almanshur. Op.Cit. 2012, 165; Sugiyono. Op.Cit, 2014, 145-7. Op.Cit., 137.

${ }^{15}$ M. Djunaidi Ghony dan Fauzan Almanshur. Op.Cit, 2012, 176; Sugiyono.

${ }^{16}$ Margono, Op. Cit, 181

${ }^{17}$ Ibrahim Bafadal dan Masykuri Bakri. Metode Penelitian Kualitatif: Tinjauan Teoritis dan Praktis. (Malang: LP UNISMA dan Visipress Media, 2013), 185-187.

${ }^{18}$ M. Djunaidi Ghony dan Fauzan Almanshur. Op.Cit, 218-220, 322-324. Lihat juga Sugiyono. Metode Penelitian Kuantitatif, Kualitatif dan $R \& D$. (Bandung: Alfabeta, 2014), 267-278.

${ }^{19}$ M. Djunaidi Ghony dan Fauzan Almanshur. Op.Cit, hal,328-329. 
Teknik analisis data yang dipakai dalam penelitian ini adalah model Spreadly, yang memiliki tahapan: (1) analisis domain, ${ }^{22}$ (2) analisis taksonomi, ${ }^{23}(3)$ dan analisis komponen ${ }^{24}$

\section{PEMBAHASAN}

\section{Menerima Perbedaan Agama}

Desa Balun bukanlah masyarakat yang hanya mengakui adanya perbedaan agama pada masyarakatnya, tetapi mereka juga menerima perbedaan agama yang ada sebagai sebuah realitas sosial obyektif yang hidup di tengah kehidupan mereka. Artinya, penerimaan perbedaan agama merupakan realitas sosial yang telah mengalami proses institusionalisasi, habitulasi, tradisisasi, dan mendapatkan legitimasi.

Dalam konteks obyektivasi, keluarga EL tidak hanya mengakui adanya perbedaan agama dalam keluarga, melainkan juga menerima perbedaan agama antara dirinya dan anaknya dengan orang tua (ayah dan ibu) dan adik-adiknya. Berdasarkan hasil wawancara, EL menyatakan bahwa ia tidak hanya mengkomunikasikan sikap pengakuannya terhadap perbedaan agama pada individu-individu yang ada di Balun, tetapi ia juga melembagakan sikap penerimaan perbedaan agama dalam dalam benak atau pikirannya, karena bagaimana seseorang bisa mengakui adanya perbedaan tanpa disertai dengan sikap penerimaan. Kemudian, EL menyatakan perlunya mendidik anaknya supaya menerima perbedaan agama yang ada di tengah keluarganya dan masyarakat Balun umumnya. Cara mendidik dilakukan oleh EL kepada anaknya, LPS, adalah cara menasehatinya untuk menerima perbedaan agama yang ada antara dirinya dengan kakek nenek, bibi-bibi dan pamannya. Bagi EL, tidak sulit untuk meminta LPS memahami dan mematuhi perintahnya, karena antara LPS dengan kakek nenek dan bibi-bibinya sudah terjalin hubungan emosional dan kekeluargaan yang sangat dekat; sehingga mudah bagi EL untuk mengajari LPS cara menerima perbedaan agama yang ada di tengah kehidupan bersama.

Sedikit berbeda dengan EL, Rik mendidik anaknya, RDP, dalam konteks menerima perbedaan agama lebih mudah, karena ia tidak perlu menjelaskan hal tersebut pada anaknya. Anaknya sudah mengerti dan memahami perbedaan agama yang ia miliki dengan neneknya, Mun. Tidak

${ }^{20}$ Ibid, 324-326.

21 Sugiyono. Op.Cit, 267-278. Lihat juga Andi Prastowo. Metode Penelitian Kualitatif dalam Perspektif Rancangan Penelitian. (Yogyakarta: 2012), 265-277.

${ }^{22}$ M. Djunaidi Ghony dan Fauzan Almanshur. Op.Cit, 304.

${ }^{23}$ Ibid.305.

${ }^{24}$ Ibid.306-7. Lihat juga Sugiyono. Op.Cit. 253-67. 
hanya itu, Rik juga tidak perlu menunjukkan adanya perbedaan agama yang ada di tengah masyarakat Balun, karena RDP sendiri sudah menyaksikan adanya perbedaan agama di Balun, sehingga ia tidak membutuhkan didikan lagi dari orang tuanya untuk menerima perbedaan agama yang ada. Dalam konteks yang demikian ini, Rik telah melakukan hal apa yang disebut Lev Vygotsky sebagai "scaffolding."

Sikap menerima perbedaan agama ini menjadi realitas sosial yang dikatakan obyektif karena telah mengalami proses institusionalisasi, di mana pikiran dan perilaku Rik dan anaknya RDP telah menerima dan mempraktekan realitas sosial menerima perbedaan agama dalam kehidupan mereka. Peneliti tidak sulit untuk membuktikan penerimaan perbedaan agama oleh RDP, karena peneliti melihat RDP makan dan nonton TV ditemani dan bersama neneknya, Mun, yang beragama Kristen. Hal ini menjadi bukti bahwa RDP tidak hanya menerima perbedaan agama secara konseptual, tetapi juga dalam perilaku atau perbuatan. ${ }^{25}$

Penerimaan 'perbedaan agama' oleh RDP dalam kehidupan seharihari menunjukan adanya proses habituasi atas realitas sosial tersebut. Artinya, RDP tidak hanya melakukan perbuatan atau perilaku yang terkait dengan realitas sosial penerimaan perbedaan agama hanya sekali atau dua kali, melainkan selalu diulang-ulang dalam kehidupannya. ${ }^{26}$

Berbeda dengan keluarga multi agama di atas, keluarga Pur tidak susah atau mengalami kesulitan dalam mendidik anak-anaknya terkait dengan realitas sosial menerima perbedaan agama karena anak-anaknya bisa mekonstruksi sendiri pengetahuan tentang adanya perbedaan agama yang bisa dimulai dari dalam keluarga mereke sendiri, kemudian di tetangga dan masyarakat Balun umumnya.

\section{Menghargai dan Menghormati Agama Lain}

Dalam konteks obyektivasi sikap toleransi anak di Balun, peneliti melihat sikap tidak mendeskritkan agama lain dan ritualnya telah mengalami proses kebenaran intersubyektif di mana realitas sosial tersebut telah diwacanakan, didiskusikan, dan lainnya, sehingga sekarang sudah menjadi realitas sosial obyektif. Namun demikian, diskusi 'tidak mendeskritkan agama lain dan ritualnya telah menjadi diskusi tentang penghormatan dan penghargaan terhadap agama lain.

Proses pelembagaan atau institusionalisasi sikap menghormati dan menghargai agama lain sendiri membutuhkan waktu dan tergantung pada masing-masing individu, sehingga tidak bisa realitas sosial ini langsung menjadi realitas yang obyektif. Realitas sosial menghormati dan menghargai

\footnotetext{
${ }^{25}$ Ibid.

${ }^{26}$ Wawancara dengan Rik tanggal 15 September 2017.
} 


\section{PENDIDIKAN MULTIKULTURAL}

agama lain pada tahap selanjutnya mengalami proses habitulasi atau pembiasaan, kemudian mengalami pengendapan.

Habitulasi atau pembiasaan menghormati dan menghargai agama lain terus mengalami pengendapan pada diri EL dan anaknya, LPS. Dari pengendapan, kita bisa menemukan pola atau bentuk penghormatan dan pengharagaan perbedaan yang bisa diteruskan pada generasi pelanjut. Habitulasi atau pembiasan yang diendapkan ini pada tahap selanjutnya melahirkan tradisisasi atau pewarisan. Dikatakan proses tradisisasi karena realitas sosial menghormati dan menghargai agama lain dilakukan berulangulang dalam kehidupan individu-idnvidu masyarakat Balun. Orang atau individu yang mengulang-ulang kebiasaan realitas sosial tersebut memiliki peran dan posisinya sendiri-sendiri. EL misalnya, ia adalah seorang ibu. Sebagai ibu, ia ingin mewariskan realitas sosial menghormati dan menghargai agama lain kepada anaknya, sehingga ia menjadi anak yang toleran. Kebiasaan baik yang telah diraih ini telah membuat EL untuk menjadikan sebagai sebuah tradisi dalam hidup bermasayarakat dengan orang lain yang berlainan agama. Proses tradisisi di mana generasi yang tua atau terlebih dulu mewariskan kepada generasi selanjutnya atau berikutnya merupakan salah satu interaksi sosial yang terjadi di proses obyektivasi.

Begitu juga, realitas sosial menghormati dan menghargai agama lain merupakan medan atau arena interaksi bagi Rik. Ia dan individu-individu yang ada di Balun melakukan interaksi sosial satu sama lainnya terkait dengan realitas ini. Interaksi antara Rik dan individu-individu terkait dengan realitas menghormati dan menghargai agama lain di desa Balun mengalami proses pelembagaan atau institusionalisasi. Proses institusionalisasi atau pelembagaan sendiri membutuhkan waktu, sehingga tidak bisa realitas sosial langsung menjadi realitas yang obyektif. Pembiasaan atau habitulasi biasanya tidak terjadi berjalan dalam waktu yang singkat atau cepat, melainkan memerlukan proses atau membutuhkan waktu, dan tergantung pada masing-masing individu.

Habitulasi atau pembiasaan 'menghormati dan menghargai agama lain' terus mengalami pengendapan pada diri Rik. Dari pengendapanpengendapan yang terkait dengan realitas sosial yang ada, kita bisa menemukan pola atau bentuk yang bisa diteruskan untuk diketahui generasi pelanjut. Habitulasi atau pembiasan yang diendapkan ini pada tahap selanjutnya melahirkan proses tradisisasi atau pewarisan karena realitas sosial 'menghormati dan menghargai agama lain' ini diulang-ulang dalam kehidupan individu-individu masyarakat Balun. Orang atau individu yang mengulang-ulang kebiasaan realitas sosial ini memiliki peran dan posisinya sendiri-sendiri. 
Pendidikan yang terkait dengan karakter untuk tidak menghina, mencemooh dan lain sebagainya membutuhkan proses dan pembiasaan. Oleh karena itu, sikap toleransi dengan tidak menghina pada mereka yang berbeda agama dan ibadah telah menjadi bagian dari hidup anak didik dan keluarga, karena pada dasarnya hidup orang beragama itu bukan itu saling menghina atau mencela, melainkan saling bekerja sama dan menolong.

Sikap toleransi dengan menghormati dan menghargai agama lain telah menjadi realitas sosial yang hidup di tengah masyarakat Balun. Realitas ini tidak hanya terjadi pada sekelompok kecil atau sebagian masyarakat Balun saja, melainkan semua masyarakat Balun mengerti dan memahaminya. Tidak ada seorang pun di Balun yang mempertanyakan realitas sosial, apakah ia seorang aparat pemerintah desa, tokoh masyarakat atau tokoh agama sendiri.

\section{Membiarkan Umat Lain Bebas Beribadah}

Untuk membiasakan individu-individu di Balun untuk tidak melakukan hal-hal yang bisa menggangu kebebasan beribadah umat agama lain, maka mereka pun melakukan usaha-usaha, di antara lewat pendidikan keluarga.

Pendidikan sebagai upaya tradisisasi sikap toleeransi dalam keluarga multi agama ini tidak dilakukan dalam jangka pendek atau dengan waktu yang sangat terbatas, melainkan dilakukan secara kontinu atau berkesinambungan dan dalam konteks atau setting yang langsung di mana umat berbeda agama hidup dalam satu rumah dan saling memberikan kebebasan pada msing-masing individu untuk menjalankan ibadah atau ritual keagamaan mereka tanpa ada gangguan, halangan, intimidasi, dan lain sebagainya dari umat yang lain.

Realitas sosial membiarkan umat lain bebas beribadah dalam keluarga EL khususnya telah menjadi realitas sosial yang obyektif karena realitas ini merupakan sesuatu yang sudah common sense di Balun dan tidak ada seorang pun warga Balun yang menentang atau menolak adanya realitas sosial ini. Sehingga, realitas sosial obyektif ini bisa dikatakan sebagai realitas sosial tidak membutuhkan legitimasi khusus lagi.

Dari fakta yang peneliti temukan pada masyarakat Balun, keluarga multi agama selain EL juga tidak pernah mendidik anak atau anggota keluarga mereka untuk menghalangi atau merintangi pelaksanaan ritual agama lain, sebaliknya mengajari anak-anak untuk berempati dan membantu keluarga yang lain dalam kenyamanan dan keamanan sehingga mereka bisa menjalankan ritual agama mereka dengan tenang dan nyaman. Sikap seperti ini bukanlah sikap yang lahir secara spontanitas, melainkan melalui proses pendidikan yang lama dan terjadi di dalam lingkungan keluarga multi agama 


\section{PENDIDIKAN \\ MULTIKULTURAL}

khususnya. Oleh karena itu, pendidikan dalam keluarga multi agama memegang peranan yang sangat penting dan siginifikan sekali dalam mengkonstruksi sikap toleransi pada anak di Balun.

\section{Memberikan Kebebasan Memilih Agama}

Bagi masyarakat Balun, memeluk agama merupakan hak asasi dari masing-masing individu, sehingga setiap orang harus diberikan kebebasan untuk memilihnya. Sebagai realitas sosial, memberikan kebebasan memilih agama merupakan realitas yang telah mengalami proses terlembagakan atau institusionalisasikan pada masyarakat Balun. Proses pelembagaan 'memberikan kebebasan memilih agama' sendiri di Balun tidak memerlukan waktu yang lama, karena secara yuridis ada payung hukum yang menjamin setiap individu yang ada untuk memiliki kebebasan beragama, dan masyarakat Balun sendiri juga tidak mempertanyakan atau mempersoalkan kebebasan beragama ini.

Proses pelembagaan kebebasan beragama bukanlah peristiwa atau realitas sosial yang mengkagetkan atau jarang terjaring terjadi atau ada, melainkan sering terjadi dan ada, sehingga masyarakat Balun tidak terkejut atau heran dengan realitas sosial itu. Dengan kata lain, masyarakat Balun telah terbiasa mengalami realitas sosial memberikan kebebasan memilih agama.

Sebagai habitulasi masyarakat Balun, kebebasan beragama menjadi sesuatu yang tidak bisa dilepaskan dari kehidupan keagamaan masyarakat Balun. Realitas sosial memberikan kebebasan memilih agama ini sendiri mengalami pengendapan dalam kehidupan masyarakat Balun, sehingga sudah tidak ada lagi orang atau individu-individu di masyarakat Balun yang menggugat atau mempertanyakannya. Ketika semua itu berlalu, maka proses tradisisasi realitas sosial memberikan kebebasan memilih agama ini menjadi sesuatu yang penting untuk dilakukan.

Kebebasan memberikan hak untuk memeluk agama sesuai dengan kehendak dan keyakinannya dikatakan sebagai bentuk toleransi yang bersifat pasif karena orang tua pada masing-masing keluarga tidak memberikan pencerahan atau penyakinan terhadap pindahnya agama anakanak mereka. Orang tua juga tidak mendorong dan mensemangati anak-anak mereka untuk berpindah agama, melainkan hanya memberikan kebebasan dan terkesan mengikuti apa yang berlaku di masyarakat, tanpa alasan atau pendirian yang lebih kokoh dan kuat.

\section{Mentolerir Pindah Agama}

Bagi masyarakat Balun, agama seseorang tidak bisa dipaksakan. Artinya, agama merupakan urusan pribadi dan menjadi hak privasi setiap 
orang. Kepindahan agama dari satu agama ke agama lain yang dilakukan oleh orang Balun merupakan sesuatu yang bisa ditolerir. Bahkan, kepindahan agama ini sendiri telah menjadi hal biasa atau lumrah bagi masyarakat Balun.

Kepindahan agama merupakan realitas yang berkembang di masyarakat Balun sampai hari ini. Dalam realitas ini individu-individu yang ada terlibat dalam interaksi yang berkenaan dengan realitas tersebut, sehingga realitas ini menjadi tidak asing lagi bagi masyarakat Balun. Sebagai realitas sosial yang tidak asing lagi atau aneh bagi masyarakat Balun, kepindahan agama telah mengalami proses terlembagakan atau institusionalisasikan. Proses terlembagakanya kepindahan agama sendiri di Balun tidak memerlukan waktu yang lama, karena secara yuridis ada payung hukum yang menjamin setiap individu yang ada untuk bebas menentukan agama agama ia mau atau kehendaki, dan masyarakat Balun sendiri juga tidak mempertanyakan atau mempersoalkan hal ini.

Realitas sosial kepindahan agama dalam pewarisan atau tradisisasinya tidak mengalami kendala atau rintangan apapu karena pola keberagamaan yang ada di Balun lebih ke arah pluralis sehingga setiap orang yang ada di Balun, termasuk orang tua memberikan kebebasan beragama dan pindah agama. Pemberian kebebasan beragama dan pindah agama ini merupakan sesuatu yang masuk akal atau common sense, karena undang-undang yang berlaku di Indonesia memberikan payung hukumnya terkait dengan realitas sosial ini. Dengan demikian, mentolerir kepindahan agama telah menjadi realitas sosial yang obyektif, realitas yang terpisah atau terlepas dari individu-individu pembuat realitas ini sendiri.

Kebebaan dalam menentukan agama tidak hanya terjadi sekarang, tetapi akan sangat mungkin pada generasi selanjutnya, karena kebebasan menentukan agama sendiri seperti disinggung di atas telah dijamin tidak hanya oleh masyarakat Balun sendiri, tetapi kitab suci al-Qur'an sudah lebih dulu menjadi sandaran pembenaran atas realitas sosial ini. Dalam keluarga besar Ibu F, Guru MTK MI Tarbiyatus Sibyan sendiri misalnya, kakeknya tidak pernah memaksakan anak-anaknya untuk beragama yang sama dengan dirinya meski ia telah menjalankan ibadah haji. Sebaliknya, ia memberikan kebebasan kepada seluruh anak-anaknya untuk memilih agama yang disukai atau diyakini mereka. ${ }^{27}$

\section{Menuju Sikap Inklusif}

Masyarakat Balun adalah masyarakat yang tidak menampilkan pola kehidupan keagamaan yang menonjolkan klaim-klaim keagamaan,

\footnotetext{
${ }^{27}$ Wawancara tanggal 18 Desember 2016
} 


\section{PENDIDIKAN MULTIKULTURAL}

melainkan menyuguhkan kehidupan yang toleran dengan sikap kehidupannya yang inklusif. Realitas sosial bersikap inklusif merupakan gelanggang interaksi antar individu-individu yang menetap di desa Balun. Mereka melakukan interaksi sosial satu sama lainnya terkait dengan entitas ini. Bagi EL sendiri, bersikap inklusif merupakan realitas sosial yang ada dan hidup di tengah masyarakat Balun. Dalam realitas sosial bersikap inklusif, EL dan individu-individu lainnya sebagai warga desa Balun berusaha untuk saling berinteraksi.

Sikap bersikap inklusif sendiri bukanlah sikap yang dibentuk dalam satu dua jam atau hari, melainkan membutuhkan kebiasaan atau habitulasi. Kebiasaan bersikap inklusif ini tampak menuai hasil pada diri LPS, di mana ia tidak melecehkan, merendahkan atau sejenisnya kepada keluarganya yang beda agama, temannya dan orang lain.

Habitulasi atau pembiasaan ini bersikap inklusif terus mengalami pengendapan pada diri EL. Dari pengendapan-pengendapan yang terkait dengan realitas sosial yang ada, kita bisa menemukan pola-pola atau bentuk yang bisa diteruskan untuk diketahui oleh orang lain atau generasi pelanjut. Habitulasi atau pembiasan yang diendapkan ini pada tahap selanjutnya melahirkan tradisisasi atau pewarisan tidak bersikap eksklusif ini dikatakan mengalami proses tradisisasi ketika realitas sosial ini diulang-ulang dalam kehidupan individu-idnvidu masyarakat Balun. Orang-orang atau individuindividu yang mengulang-ulang kebiasaan realitas sosial tersebut memiliki peran dan posisinya sendir-sendiri.

\section{Bahasan}

Berdasarkan hasil penelitian, peneliti menemukan adanya proses obyektivasi yang dilakukan oleh keluarga multi agama ketika mereka mengobyektivasi sikap toleransi anak. Proses obyektivasi ini penting dibahas karena di dalam proses obyektivasi ini kita bisa membedakan atau memisahkan antara individu-individu (orang tua keluarga multi agama) sebagai pencipta realitas sosial dengan realitas sosial sendiri. Dengan kata lain, realitas sosial seperti menerima perbedaan agama, menghargai dan menghormati agama lain, memberikan kebebasan beribadah bagi umat lain, dan lain-lain merupakan suatu faktisitas yang berada di luar dan berlainan dari diri individu-individu yang menghasilkannya.

Realitas sosial seperti menerima perbedaan agama, menghargai dan menghormati agama lain, memberikan kebebasan beribadah bagi umat lain, dan lain-lain pada satu sisi merupakan suatu dunia yang berasal dari pikiranpikiran dan tindakan-tindakan orang tua dalam keluarga dan masyarakat yang ada di desa Balun, namun pada sisi yang lain realitas-realitas tersebut dipelihara sebagai sesuatu yang nyata oleh pikiran dan tindakan orang tua 
dalam keluarga multi agama dan masyarakat Balun umumnya. Tindakan pemeliharaan realitas sosial ini orang tua dalam keluarga multi agama dan masyarakat Balun umumnya dilakukan dengan proses dan pemaknaan yang bersifat intersubyektif. ${ }^{28}$ Artinya, setiap individu dalam keluarga multi agama maupun pada masyarakat Balun memberikan interpretasi atau pemaknaan yang bisa sama atau berbeda antara satu dengan lainnya. Pemaknaan bersama antar individu (pemaknaan intersubyektif) dalam masyarakat Balun terhadap realitas-realitas sosial dalam proses obyektivasi ini menyebabkan realitas-realitas tersebut menjadi realitas yang bersifat obyektif. Artinya, setiap akal sehat individu-individu di masyarakat Balun mengakui dan menerima realitas-realitas sosial baru tersebut sebagai realitas sosial yang obyektif. ${ }^{29}$

Beragam sikap toleransi pada para individu dan anak-anak keluarga multi agama yang telah menjadi realitas obyektif di tengah masyarakat Balun setidaknya telah menandakan bahwa beragam sikap toleransi baru tersebut sedang mengalami proses institusionalisasi. Proses institusionalisasi sendiri bisa dikatakan sebagai proses pelembagaan beragam model toleransi yang ada pada anak sebagai bentukan atau ciptaan orang tua dalam keluarga multi agama di masyarakat Balun, baik pada tataran pikiran, perilaku atau lainnya yang dilakukan secara berulang-ulang, dan membutuhkan waktu yang cukup relatif lama, dan akan terlihat polanya serta bisa dipahami oleh individu-individu lain yang ada di masyarakat Balun secara bersama-sama. Beraneka sikap toleransi yang ditampilkan atau ditunjukan oleh anak-anak keluarga multi agama secara berkelanjutan atau terus menerus pada akhrinya menghasilkan habitulasi (pembiasaan).

Peran orang tua sebagai pendidik, dan berperan sebagai mediator atau fasilitator ini sejalan dengan penyataan Paul Suparno bahwa orang tua (pendidik) dan anak (peserta didik) lebih sebagai mitra yang bersama-sama membangun pengetahuannya. Namun demikian, anak (didik) dituntut lebih aktif dalam pendidikannya untuk mengkonstruksi pengetahuannya secara mandiri, dan pada akhirnya mereka sendiri yang akan dan harus bertanggung jawab pada hasil belajar mereka. ${ }^{30}$.

Terkait dengan orang tua yang berperan sebagai pendidik yang berfungsi mediator, fasilitator dan mitra dalam proses pendidikan konstruktivistik, John W. Santrock menuntut orang tua: i) menyediakan

${ }^{28} \mathrm{Ibid}, 28$.

${ }^{29}$ Mengenai pemisahan antara realitas subyektif dan realitas obyektif, lihat Hanneman Samuel, Perspektif Sosiologis Peter Berger, Pusat Antar Universitas Bidang Ilmu-ilmu Sosial Universitas Indonesia. 1993, 9.

${ }^{30}$ Paul Suparno. Fisafat Konstruktifisme dalam Pendidikan, (Jogjakarta: Kanisius, 1977), 3. 
pengalaman belajar yang memungkinkan anak didik bertanggung jawab dalam membuat rancangan, proses dan penelitian, ii) menyediakan atau memberi kegiatan-kegitan yang merangsang keingintahuan anak didik, dan membantu mereka mengekspresikan gagasan-gagasan mereka kemudian mengkomunikasikan ide-ide tersebut, iii) menyediakan sarana yang merangsang anak didik untuk berpikir secara aktif produktif, iv) menyediakan kesempatan dan pengalaman yang paling mendukung bagi proses pendidikan anak didik, v) memonitor, mengevaluasi, dan menunjukkan keberhasilan dan kekurang- berhasilan anak didik, ${ }^{31}$ dan vi) membantu mengevaluasi hipotesis dan kesimpulan yang dibuat oleh anak didik. Sedangkan Muhibbinsyah menegaskan perlunya orang tua sebagai pendidik dalam konstruksionisme untuk lebih memahami jalan pikiran atau pandangan anak (didik) terkait gaya belajar mereka. Sehingga, orang tua (pendidik) tidak bisa mengklaim bahwa metode hanya satu dan bisa diterapkan pada segala satunya cara yang tepat adalah yang sama dan sesuai dengan kemauannya. Dengan kata lain, seorang pendidikan harus memahami student learning style (gaya belajar setiap anak didik). ${ }^{32}$ Lebih lanjut, John W. Santrock mengatakan bahwa peran kunci pendidik yang tidak kalah penting dalam interaksi pendidikan dalam pendekatan konstruksionisme adalah pengendalian, yang meliputi: a) menumbuhkan kemandirian dengan menyediakan kesempatan untuk mengambil keputusan dan bertindak, b) menumbuhkan kemampuan mengambil keputusan dan bertindak dengan meningkatkan pengetahuan dan keterampilan siswa, dan c) menyediakan system dukungan yang memberikan kemudahan belajar agar siswa mempunyai peluang optimal untuk berlatih. ${ }^{33}$

Peran yang dimainkan oleh orang tua dalam pendidika anak di dalam keluarga, mengendapkan beragam sikap toleransi yang telah menjadi realitas obyektif dalam pikiran dan perilaku akan membuat beragam sikap toleransi baru yang ada di tengah masyarakat Balun menjadi tertradisisasikan atau diwariskan. Dengan kata lain, setelah mengalami proses pengendapan, beragam sikap toleransi yang ada pada anak-anak keluarga multi agama dan individu-idnvidu yang ada di Balun sendiri mentradisisasikan beragam sikap toleransi. Beragam sikap toleransi yang ada di masyarakt Balun sekarang, dan sedang mengalami proses tradisisasi, pada gilirannya beragam sikap toleransi tersebut akan diwariskan kepada generasi selanjutnya melalui bahasa. Bahasa dalam konteks ini memiliki peran yang sangat penting bagi keberhasilan atau kesuksesan tradisisasi

\footnotetext{
${ }^{31}$ John W. Santrock. Op.Cit, 255-256.

${ }^{32}$ Muhibbin Syah. Psikologi Pendidikan dengan Pendekatan Baru, (Bandung: Remaja Rosdakarya, 2013), hal, 229-234.

${ }^{33}$ John W. Santrock. Op.Cit; 253.
} 
beragam sikap toleransi dari satu generasi ke generasi selanjutnya. Bahasa dalam konteks ini tidak hanya bahasa lisan atau tulis, melainkan juga simbol, tetanda, dan lainnya yang memiliki arti atau maksud tersendiri atau tersembunyi, namun diketahui orang banyak. ${ }^{34}$ Namun demikian, beragam sikap toleransi yang ada tersebut masih melibatkan proses legitimasi di dalamnya. Mengapa demikian? Karena legitimasi ini berfungsi untuk membuat beragam realitas sosial (beragam sikap toleransi) yang sudah melembaga bisa diterima oleh setiap penduduk desa Balun.

Melihat proses pendidiakan yang berlangsung dalam keluarga multi agama dalam mengobyektivasi sikap toleransi pada anak mereka, peneliti menyimpulkan tujuan utama pendidikan mereka adalah mewariskan nilainilai luhur dan budaya masyarakat Balun kepada anak-anak.

Karena, masyarakat Balun mempunyai nilia-nilai budaya luhur yang ingin disalurkan dari generasi ke generasi, maka identitas-identitas masyarakat Balun tersebut harus tetap terpelihara dan terjaga. Nilai-nilai budaya luhur yang ingin ditransfer atau dipindahkan kepada generasi selanjutnya bisa berupa atau bersifat intelektual, seni, politik, dan lainlain. Hasan Langgulung juga menyatakan bahwa interaksi antara masyarakat dan individu dalam sebuah lingkungan pendidikan bisa mengembangkan potensi dan bakatnya untuk memperbaiki kondisi lingkungan pendidikan. ${ }^{35}$ Hal ini sejalan dengan teori konstruksi Lev Vygotsky tentang sosio-kultural, yang akan diurakan tersendiri pada sub-bab ini. Lebih lanjut, Hasan Langgulung menyatakan bahwa pewarisan budaya (transmission of culture) adalah proses mewariskan budaya (unsur-unsur budaya dari satu generasi ke generasi manusia atau masyarakat berikutnya melalui proses pembudayaan (proses belajar budaya). Menimjam istilah Berger dan Luckmann, proses pewarisan nilai-nilai tersebut melewati proses yang disebut tradisisasi. Sesuai dengan hakikat dan budaya sebagai pemilik bersama masyarakat maka unsur-unsur kebudayaan itu memasyarakat dalam individu-individu warga masyarakat dengan jalan diwariskan atau dibudayakan melalui proses belajar budaya. Proses pewarisan budaya dilakukan melalui proses enkulturasi (pembudayaan) dan proses sosialisasi (belajar atau mempelajari budaya).

Pendidikan anak menurut pandangan Islam yang harus dilakukan dalam keluarga adalah dengan menggunakan beberapa pola pendidikan. Pola atau dapat disebut juga sebagai metode merupakan suatu cara yang dilakukan oleh pendidik dalam menyampaikan nilai-nilai atau materi

\footnotetext{
${ }^{34}$ Untuk keterangan lebih detail tentang peran bahasa dalam realitas obyektif, lihat Soerjono Soekanto. Sosiologi: Suatu Pengantar. (Jakarta: Rajawali Press, 2012), 212.

${ }^{35}$ Hasan Langgulung, Pendidikan Islam Indonesia; Mencari Kepastian Historis, dalam Islam Indonesia Menatap Masa Depan (Jakarta: P3M, 1989), 161.
} 


\section{PENDIDIKAN MULTIKULTURAL}

pendidikan pada peserta didik untuk mencapai tujuan pendidikan itu sendiri sebagai salah satu komponen penting dalam proses pendidikan. Pola atau metode dituntut untuk selalu dinamis sesuai dengan dinamika dan perkembangan peradaban manusia. Pola atau metode pendidikan agama dalam Islam pada dasarnya mencontoh pada perilaku Nabi Muhammad SAW dalam membina keluarga dan sahabatnya. Karena segala apa yang dilakukan oleh Nabi Muhammad SAW merupakan manifestasi dari kandungan al-Quran. Adapun dalam pelaksanaannya, Nabi memberikan kesempatan pada para pengikutnya untuk mengembangkan cara sendiri selama cara tersebut tidak bertentangan dengan prinsip-prinsip pelaksanaan pendidikan yang dilakukan oleh Nabi.

Berdasarkan temuan hasil penelitian, peneliti mendapatkan beragam metode pendidikan yang dipakai oleh orang tua dalam keluarga multi agama untuk mengobyektivasikan sikap toleransi anak adalah sebagai berikut:

\section{1) Metode pembiasaan}

Metode ini merupakan metode di mana orang tua sebagai pendidik melakukan kegiatan secara teratur dan berkesinambungan untuk melatih anak atau peserta didik memiliki kebiasaan-kebiasaan tertentu, yang umumnya berhubungan dengan pengembangan kepribadian anak seperti emosi, disiplin, budi pekerti, kemandirian, penyesuaian diri, hidup bermasyarakat, dan lain sebagainya. Sehingga, ketika mendidik anak, orang tua sebagai pendidik tidak hanya menggunakan metode ceramah atau penjelasan tentang materi yang sedang diajarkan, melainkan juga harus membiasakan materi-materi yang positif menjadi sifat atau karaktek anak dalam kehidupan keseharian. ${ }^{36}$

. Dalam pembinaan sikap, metode pembiasaan sangat efektif digunakan karena akan melatih kebiasaan-kebiasaan yang baik kepada anak sejak dini. Pembiasaan merupakan penanaman kecakapan-kecakapan berbuat dan mengucapkan sesuatu, agar cara-cara yang tepat dapat disukai oleh anak. Pembiasaan pada hakikatnya mempunyai implikasi yang lebih mendalam daripada penanaman cara-cara berbuat dan mengucapkan. ${ }^{37}$

Metode pembiasaan dalam bidang psikologi pendidikan dikenal dengan istilah operan conditioning. Operan conditioning sendiri sering dipahami sebagai metode yang mengajarkan peserta didik untuk membiasakan perilaku terpuji, disiplin, giat belajar, bekerja keras, ikhlas, jujur, dan bertanggung jawab atas setiap tugas yang telah diberikan. H. E. Mulyasa, ed. Dewi Ispurwanti menyatakan bahwa Pembiasaan adalah

\footnotetext{
${ }^{36}$ Helmawati. Op.Cit; 60-61.

${ }^{37}$ Muhammad Fadlillah dan Lilif Mualifatu Khorida, Pendidikan Karakter Anak Usia Dini: Konsep dan Aplikasinya dalam PAUD, (Jogjakarta: Ar-Ruzz Media, 2013), 172174
} 
sesuatu yang sengaja dilakukan secara berulang-ulang agar sesuatu itu dapat menjadi kebiasaan. Pembiasaan sebenarnya berintikan pengalaman, yang dibiasakan adalah sesuatu yang diamalkan. Pembiasaan menentukan manusia sebagai sesuatu yang diistemawakan, yang dapat menghemat kekuatan, karena akan menjadi kebiasaan yang melekat dan spontan agar kekuatan itu dapat dipergunakan untuk berbagai kegiatan dalam setiap pekerjaan dan aktivitas lainnya. ${ }^{38}$ Sementara itu, Armai Arief menilai pembiasaan sangat efektif jika penerapanya dilakukan terhadap peserta didik yang berusia kecil. Karena memiliki rekaman ingatan yang kuat dan kondisi kepribadian yang belum matang, sehingga mereka mudah terlarut dengan kebiasaan-kebiasaan yang mereka lakukan sehari-hari. Oleh karena itu, sebagai awal dalam proses pendidikan, pembiasaan merupakan cara yang efektif dalam menanamkan nilai-nilai moral kedalam jiwa anak. Nilai-nilai yang tertanam dalam dirinya ini kemudian akan termanifestasikan dalam kehidupanya semenjak ia mulai melangkah keusia remaja dan dewasa. ${ }^{39}$

Dalam kehidupan sehari-hari, pembiasaan merupakan hal yang sangat penting, karena banyak dijumpai orang berbuat dan berperilaku hanya karena kebiasaan semata-mata. Pembiasaan dapat mendorong mempercepat perilaku, dan tanpa pembiasaan hidup seseorang akan berjalan lamban, sebab sebelum melakukan sesuatu harus memikirkan terlebih dahulu apa yang akan dilakukannya. Menurut H. E. Mulyasa dan Dewi Ispurwanti, metode pembiasaan perlu diterapkan oleh guru dalam proses pembentukan karakter, untuk membiasakan peserta didik dengan sifat-sifat terpuji dan baik, sehingga aktivitas yang dilakukan oleh peserta didik terekam secara positif. ${ }^{40}$

Muhammad Fadlillah dan Lilif Mualifatu Khorida menyatakan bahwa penerapan metode pembiasaan dapat dilakukan dengan membiasakan anak untuk mengerjakan hal-hal positif dalam keseharian mereka. Dengan melakukan kebiasaan-kebiasaan secara rutinitas setiap harinya, anak didik akan melakukan dengan sendirinya, dengan sadar tanpa ada paksaan. Dengan pembiasaan secara langsung, anak telah diajarkan disiplin dalam melakukan dan menyelesaikan suatu kegiatan. Disebabkan pembiasaan berintikan pengulangan, metode pembiasaan juga berguna untuk menguatkan hafalan. ${ }^{41}$ Rasulullah pun melakukan metode pembiasaan dengan melakukan berulang-ulang dengan doa yang sama. Akibatnya, beliau hafal benar doa itu, dan sahabatnya. Hal tersebut menunjukan bahwa

${ }^{38}$ H. E. Mulyasa, ed. Dewi Ispurwanti, Manajemen Pendidikan Karakter, (Jakarta: Bumi Aksara, 2003), 166

${ }^{39}$ Armai Arief, Op.Cit., 110

${ }^{40}$ H. E. Mulyasa, ed. Dewi Ispurwanti, Op.Cit, 167

${ }^{41}$ Muhammad Fadlillah dan Lilif Mualifatu Khorida, Op.Cit, 117. 


\section{PENDIDIKAN MULTIKULTURAL}

dengan seringnya pengulangan-pengulangan akan mengakibatkan ingataningatan sehingga tidak akan lupa. Pembiasaan tidaklah memerlukan keterangan atau argumen logis. Pembiasaan akan berjalan dan berpengaruh karena semata-mata oleh kebiasaan itu saja. ${ }^{42}$

Dalam teori perkembangan peserta didik, kita mengenal teori konvergensi, di mana pribadi dapat dibentuk oleh lingkungannya dan dengan mengembangkan potensi dasar yang ada padanya. Potensi dasar ini dapat menjadi penentu tingkah laku. Oleh karena itu, potensi dasar harus selalu diarahkan agar tujuan pendidikan dapat tercapai dengan baik. ${ }^{43}$ Menurut Armai Arief, salah satu cara yang dapat dilakukan untuk mengembangkan potensi dasar tersebut adalah melalui kebiasaan yang baik. Al-Qur'an sebagai sumber ajaran Islam, menurut prinsip-prinsip umum pemakaian dalam pemakaian metode pembiasaan dalam proses pendidikan. Dalam merubah sebuah prilaku negatif misalnya,

Al-Qur'an memakai pendekatan pembiasaan yang dilakukan secara berangsur-angsur. Kasus pengharaman khamar misalnya, Al-Qur'an menggunakan beberapa tahap ${ }^{44}$ Sebagaimana gambaran umum dalam firman Allah: "Dan dari buah korma dan anggur, kamu buat minimuman yang memabukkan dan rezeki yang baik. Sesunggguhnya pada yang demikian itu benar-benar terdapat tanda (kebesaran Allah) bagi orang yang memikirkan." (Q.S An-Nahl:27). Ayat ini memberikan penjelasan hanya sebatas tentang manfaat yang dapat diperoleh dari buah korma dan anggur agar mereka merasakan demikian besarnya kemahakuasaan Allah.

Meminum khamar adalah perbuatan dan kebiasaan yang tidak terpuji. Sebagian di antara kaum muslimin telah menyadari dan membiasakan diri untuk tidak lagi meminum-minuman yang memabukkan. Namun masih ditemukan juga sebagian yang lain merubah kebiasaan tersebut, sampai-sampai ingin melakukan shalat pun mereka melakukan kebiasaan tersebut. ${ }^{45}$

Pendekatan pembiasaan sesungguhnya sangat efektif dalam menanamkan nilai-nilai positif kedalam diri anak didik, baik pada aspek kognitif, afektif dan psikomotorik. Selain itu, pendekatan pembiasaan juga dinilai sangat efektif dalam mengubah kebiasaan negative menjadi positif. Namun demikian, pendekatan ini jauh dari keberhasilan jika tidak diiringi dengan contoh tauladan yang baik dari si pendidik.

2) Metode keteladanan

${ }^{42}$ Ibid, 118.

43 Sumardi Suryabrata. Psikologi Pendidikan, (Jakarta: Rajagrafindo Persada, 2012), 180.

${ }^{44}$ Armai Arief, Op.Cit, 111.

${ }^{45}$ Ibid, 113. 
Metode keteladanan sendiri bisa diartikan sebagai metode atau cara yang dipakai oleh orang tua untuk mendidik anak mereka dengan jalan memberikan contoh langsung, dan anak juga bisa langsung meniru apa yang dilakukan oleh orang tuanya, baik yang berupa perkataan, perbuatan, cara berfikir, dan yang lainnya. Oleh karena itu, orang tua harus waspada ketika mereka bersikap, berperilaku, bertutur, dan lainnya di hadapan anak mereka.

Dalam konteks kehidupan keluarga multi agama di Balun, kita setidaknya menemukan pemakaian metode keteladanan ini ketika orang tua tidak pernah mendeskritkan agama nenek-nenek, bibi-bibi dan paman di hadapan anak-anak mereka, dan hasilnya peneliti tidak pernah mendengar atau melihat anak-anak keluarga multi agama ini menghina atau merendahkan agama teman-temannya di sekoah maupun di rumah.

Keteladanan merupakan salah satu metode pendidikan yang diterapkan Rasulullah SAW dan dianggap paling banyak pengaruhnya terhadap keberhasilan menyampaikan misi da'wahnya. Sebagai umat Islam, sudah seharusnya mencontoh perilaku Nabi Muhammad SAW, karena dalam dirinya telah ada keteladanan yang mencerminkan ajaran al-Quran. Di samping itu, keluarga multi agama juga menggunakan adat kebiasaan yang berlaku di Balun sebagai pendekatan pendidikan. Hal ini bisa dilakukan karena setiap manusia yang dilahirkan membawa potensi, salah satunya berupa potensi beragama. Potensi beragama ini dapat terbentuk pada diri anak (manusia) melalui 2 faktor, yaitu: 1) faktor pendidikan Islam yang utama, dan 2) faktor pendidikan lingkungan yang baik.

Pada umur kanak-kanak kecenderungan anak adalah meniru apa yang dilakukan oleh orang-orang di sekitarnya, baik saudara famili terdekatnya ataupun bapak ibunya. Oleh karena itu patut menjadi perhatian semua pihak, terutama orang tuanya selaku figur yang terbaik di mata anaknya. Jika orang tua menginginkan putra putrinya tumbuh dengan menyandang kebiasaan-kebiasaan yang baik dan akhlak terpuji serta kepribadian yang sesuai ajaran Islam, maka orang tua harus mendidiknya sedini mungkin dengan moral yang baik. Karena tiada yang lebih utama dari pemberian orang tua kecuali budi pekerti yang baik. ${ }^{2}$

3) Metode pembinaan

Metode pendidikan yang dipakai juga oleh orang tua dalam mengobyektivasi sikap toleransi pada anak adalah metode pembinaan. Metode pembinaan sering dimaknai sebagai arahan atau bimbingan yang intensif terhadap diri anak didik sehingga ia akan tumbuh pemahaman yang mendalam dan kesadaran untuk berperilaku yang sesuai dengan dengan bimbingan yang diberikan. ${ }^{46}$

\footnotetext{
${ }^{46}$ Helmawati. Op.Cit; 62-63
} 


\section{PENDIDIKAN MULTIKULTURAL}

4) Metode Nasihat

Al-Quran mewajibakn umat Islam untuk mendidik dengan bijaksana atau hikmah dan memberikan pelajaran yang baik. Ada pelajaran bahwa dalam memberi nasehat kita hendaknya melakukannya dengan baik. Jika ada orang yang membantah, maka kita harus membantahnya dengan baik. Sehingga nasehat yang kita berikan bisa diterima dengan lapang dada, tanpa ada unsur terpaksa.

Dalam agama Islam, nasehat sendiri menempati kedudukan yang sangat tinggi karena agama sendiri adalah nasehat. Nabi Muhammad harus tiga kali mengatkan ketika memberi pelajaran atau nasehat kepada para sahabatnya. Sehingga, seorang pendidik dituntut untuk memperhatikan caracara menyampaikan dan memberikan nasehat, yakni ketika memberikan nasehat, hendaknya kita menyesuaikan dengan situasi dan kondisi. Sehingga, seorang pendidik harus selalu sabar dalam menyampaikan nasehat dan tidak boleh merasa bosan, apalagi putus asa. Di amping itu, pendidik juga memperhatikan waktu dan tempat tepat sehingga anak menerima nasehat dengan baik dan legowo dari pendidik.

Melihat kembali paparan temuan penelitian, peneliti menilai dua anak (LPS dan WRS) merupakan anak yang mampu melakukan sesuatu (tugas, perintah atau lainnya) di atas kemampuannya, namun hal tersebut sangat terbatas, sehingga ia masih tetap membutuhkan orang yang lebih mengetahui, mengerti, mengerjakan, mempraktekan, dan lain sebagainya. Melakukan realitas sosial 'berlomba melakukan kebaikan atau bersikap inklusif' misalnya merupakan tugas atau perintah yang sangat mungkin bisa dikerjakan atau dilakukan oleh LPS atau WRS, dan mereka sudah mampu melakukannya, meskipun mereka belum mengerti sepenuh apa berlomba-lomba dalam kebaikan yang diingini, atau bagaimana bersikap inklusif, namun dalam tataran kehidupan sehari-hari, mereka sudah menjalaninya. Kemampuan mengerjakan sesuatu secara maksimal dan berlebih, meski usia mereka belum mengizinkan. Hal ini yang disebut Zone of Proximal Development (ZPD).

Vygotsky mendefinisikan ZPD sebagai jarak antara tingkat perkembangan aktual anak sebagaimana ditentukan oleh kemampuan memecahkan masalah secara mandiri dan tingkat perkembangan potensial sebagaimana ditentukan oleh pemecahan masalah di bawah bimbingan orang dewasa atau kerjasama dengan sebaya yang mampu. ${ }^{47}$ Vygotsky sendiri mengatakan bahwa pengetahuan, pemahaman, dan keterampilan anak tidak datang dengan tiba-tiba, melainkan hasil dari interaksi yang dilakukan oleh anak dengan lingkungan dan sosio-kultural yang

${ }^{47}$ John W. Santrock. Life Span Development, (New York: McGraw Hill, 2012), hal. 252-258. 
melingkupi, dihadapi dan dialaminya. Sehingga, ketika anak semakin bergaul atau berinteraksi denga lingkungan atau sosial budaya, maka ia akan semaki memiliki pengetahuan, pemahaman dan perkembangan serta keterampilan. ${ }^{48}$

Kita banyak menemukan orang yang mau berbicara A, namun ketika keluar menjadi B. hal ini menunjukkan adanya ketidaksinkroninan antara inner speech dan ucapan, tindakan atau lainnya yang nyata. Akhirnya, Vygotsky menegaskan bahwa pikiran seseorang berkembang untuk merefleksikan kenyataan sosial. Proses komunikasi dengan orang lain menghasilkan perkembangan makna kata yang kemudian membentuk struktur kesadaran. Oleh karena itu, Vygotsky mengklaim bahwa pola piker dalam atau pembicaraan batini tidak mungkin ada tanpa interaksi sosial. ${ }^{49}$

Penelitian ini menemukan adanya konstruksi sikap toleransi yang dilakukan oleh anak-anak keluarga multi agama dengan menjadikan budaya atau lingkungan sosial, atau hubungan antar individu sebagai basis menyusun pengetahuan, pemahaman dan keterampilan. Sehingga, peneliti menilai bahwa anak-anak yang mampu memanfaatkan budaya dan menggunakan pengetahuan atau pemahaman sebelumnya, maka mereka cepat mengalami perkembangan dan peningkatan pengetahuan, keterampilan dan lainnya. Hal ini sesuai dengan pendekatan konstruksionisme Lev Vygotksy bahwa kelompok di mana individu berada, sangat menentukan proses pembentukan pengetahuan pada diri seseorang. Melalui komunikasi dengan komunitasnya, pengetahuan seseorang dinyatakan kepada orang lain sehingga pengetahuan itu mengalami verifikasi, dan penyempurnaan.

Melalui komunikasi seseorang memperoleh informasi atau pengetahuan baru dari masyarakatnya. Lebih lanjut, Vygotsky menandaskan bahwa kematangan fungsi mental anak justru terjadi lewat proses kerjasama dengan orang lain, seperti dinyatakan oleh Newman 'the maturation of the child's higher mental functions occurs in this cooperative process, that is, it occurs through the adult's assistance and participation. ${ }^{50}$ Konstruktivisme sosial Lev Vygotsky ini menekankan bahwa pembentukan ilmu pengetahuan merupakan hasil pembentukan individu bersama-sama dengan masyarakat sekitarnya. Hal ini seide dengan pernyataan Piaget 'there is no longer any need to choose between the primacy of the social or that of the intellect; the collective intellect is

${ }^{48}$ Ibid; $252-258$.

${ }^{49}$ Ibid.

${ }^{50}$ Newman, F. et. al. Lev Vygotsky, Revolutionary Scientist, (London and New York:Routledge, 1993), 7 , 


\section{PENDIDIKAN MULTIKULTURAL}

the social equilibrium resulting from the interplay of the operations that enter into all cooperation. ${ }^{51}$

Karena pengetahuan seseorang dibangun secara pribadi dalam interaksinya dengan masyarakat dan lingkungannya, maka pengetahuan yang dibawa oleh peserta didik ke dalam kelas dinilai sebagai sumber penting untuk membangun pengetahuan baru. Sehingga, konstruksivisme sosial menghargai pandangan bahwa pengetahuan peserta didik yang dibawa ke dalam kelas sekalipun berbeda dengan keyakinan yang dianut oleh para ilmuwan, amatlah penting. Sekalipun pengetahuan para peserta didik itu berbeda dengan yang diakui di dalam khasanah ilmu pengetahuan, konsepsi mereka tidak pertama-tama dilihat sebagai sebuah konsep yang "salah", melainkan diakui sebagai sebuah konsep alternatif.

Hal lain yang peneliti temukan adalah adanya bantuan yang diberikan oleh orang tua kepada anak-anak mereka dalam mengobyektivasikan sikap toleransi mereka. Lev Vygotsky menyebut bantuan ini dengan nama scaffolding. Vygotsky mendefinisikan scaffolding sebagai pemberian sejumlah bantuan kepada anak didik pada tahap awal pembelajaran, kemudian mengurangi dan member kesempatan kepada anak untuk mengambil alih tanggung jawab saat mereka mampu. Bantuan tersebut berupa petunjuk, perintah, peringatan, dorongan, menguraikan masalah pada langkah-langkah pemecahan, memberi contoh ataupun halhal lain yang memungkinkan pelajar tumbuh mandiri.

\section{PENUTUP}

Untuk memuluskan proses obyektivasi sikap toleransi pada anak, orang tua dalam keluarga multi agama menggunakan metode pendidikan dalam Islam. Metode pendidikan yang dipakai dalam proses obyektivasi sikap toleransi pada anak adalah (1) metode pembiasaan, (2) metode keteladanan, (3) metode pembinaan, dan (4) metode nasihat. Tidak hanya itu, orang tua sebagai pendidik juga melakukan (i) penyediaan pengalaman belajar yang memungkinkan anak bertanggung jawab dalam membuat rancangan, proses dan penelitian, (ii) penyediaan atau pemberian kegiatankegitan yang merangsang keingintahuan anak, dan membantu mereka mengekspresikan gagasan-gagasan mereka kemudian mengkomunikasikan ide-ide tersebut., dan (iii) penyediaan sarana yang merangsang anak didik untuk berpikir secara aktif produktif, (iv) penyediaan kesempatan dan pengalaman yang paling mendukung bagi proses pendidikan anak, v)

${ }^{51}$ J. Piaget. The psychology of Intelligence, (Totawa: Littlefield, Adam \& Co, 1981), Lihat juga, J. Piaget, Psychology and Epistemology, (New York: The Viking Press, 1971), 15 
pemonitoran, pengevaluasian, dan penunjukkan keberhasilan dan kekurangberhasilan anak didik, dan (vi) bantuan mengevaluasi hipotesis dan kesimpulan yang dibuat oleh anak didik.

\section{DAFTAR PUSTAKA}

Alison Mackey, 2005, Second Language Research: Methodology and Design. New Jersey: Lawrence Erlbaum Associates, Inc.

Andi Prastowo. 201, Metode Penelitian Kualitatif dalam Perspektif Rancangan Penelitian. Yogyakarta.

Bruce L Berg. 1989, Qualitative Research Methods for the Social Science. USA: Allyn dan Bacon.

David Silvermen. 1995, Interpreting Qualitative Data: Methods for Analyzing Talk, Text, and Interaction. Great Britain: the Crowell Press, ltd.

Donald Ary et.all. tt, Introduction to Research in Education. USA: Holt Rinehart and Winston..

F Newman, et. al. 1993, Lev Vygotsky, Revolutionary Scientist. London and New York:Routledge.

Geoffrey Marczyk, David DeMatteo, and David Festinger. 2005, Essentials of Behavioral Science Series. New Jersey: John WiELy \& Sons, Inc..

Hanneman Samuel, 1993, Perspektif Sosiologis Peter Berger, Pusat Antar Universitas Bidang Ilmu-ilmu Sosial Universitas Indonesia.

Hasan Langgulung, 1989, Pendidikan Islam Indonesia; Mencari Kepastian Historis, dalam Islam Indonesia Menatap Masa Depan. Jakarta: P3M.

H. E. Mulyasa, ed. Dewi Ispurwanti, 2003, Manajemen Pendidikan Karakter. Jakarta: Bumi Aksara.

Ibrahim Bafadal dan Masykuri Bakri. 2013, Metode Penelitian Kualitatif: Tinjauan Teoritis dan Praktis. Malang: LP UNISMA dan Visipress Media.

Imron Arifin. 1994, Penelitian Kualitatif dalam Ilmu-ilmu Sosial dan Keagamaan. Malang: Kalimasahada Press.

James Dean Brown. tt, Understanding Research in Second Language ELarning. NY: Cambridge Univ. Press.

Jan Jocker dan Bartjan Pennink. 2010, The Essence of Research Methodology: A Concise Guide for Master and PhD Students in Management Science. Berlin: Springer. 
PENDIDIKAN

MULTIKULTURAL

James Spreadly. 1980, Participant Observation. USA: Holt Rinehart and Winston.

John W. Creswell. 2014, Penelitian Kualitatif \& Desain Riset. Yogyakarta:

Pustaka Pelajar.

John W. Santrock. 2012, Life Span Development. New York: McGraw Hill. J. Piaget. 1981, The psychology of Intelligence. Totawa: Littlefield, Adam \& Co. Press..

1971, Psychology and Epistemology. New York: The Viking

Matthew MiELs B \& A. Michael Huberman, tt, Analisis Data Kualitatif. Terj. Tjejep Rohendi. Jakarta: UI.

Mudrajat Kuncoro, 2003, Metode Riset. Jakarta: Erlangga.

Muhammad Fadlillah dan Lilif Mualifatu Khorida, 2013, Pendidikan Karakter Anak Usia Dini: Konsep dan Aplikasinya dalam PAUD. Jogjakarta: Ar-Ruzz Media, 2013.

Muhibbin Syah. 2013, Psikologi Pendidikan dengan Pendekatan Baru. Bandung: Remaja Rosdakarya..

Paul Suparno. 1997, Fisafat Konstruktifisme dalam Pendidikan, Jogjakarta: Kanisius.

Parsudi Suparlan. 1994, Metode Penelitian Kualitatif. Jakarta: Program Kajian Wilayah Amerika UI.

Poedjiadi, A. 2005, Sains Teknologi Masyarakat; Model Pembelajaran Kontekstual Bermuatan Nilai. Bandung : Remaja Rosdakarya.

Robert Bogdan \& Steven J. Taylor. 1975, Dasar-dasar Penelitian Kualitatif. Terj. A. Khozin Afandi. Surabaya: Usaha Nasional.

Roger E Cavallo. 1979, The RoEL of Systems Methodology in Social Sciences Research. Boston: Martinus Nijhoff Publishing.

Sharlene Nagy and Hesse-Biber. 2010, Mixed Methods Research: Merging Theory with Practice. New York: The Guilford Press.

Soerjono Soekanto. 2012, Sosiologi: Suatu Pengantar. Jakarta: Rajawali Press.

Sugiyono. 2014, Metode Penelitian Kuantitatif, Kualitatif dan $R \& D$. Bandung: Alfabeta.

Sumardi Suryabrata. 2012, Psikologi Pendidikan. Jakarta: Rajagrafindo Persada.

Thomas R. Lindlof. 1995, Qualitative Communication Research Methods. USA: SAGE Publications, Inc

Yogesh Kumar Singh. 2006, Fundamental of Research Methodology and Statistic. Delhi: New Age International. 
OBYEKTIVASI SIKAP TOLERANSI ANAK DALAM PENDIDIKAN ISLAM MULTIKULTURAL KELUARGA MULTI AGAMA (Nasruddin) 